\title{
ANALISIS VARIASI KATA SAPAAN ANTARA PENJUAL DAN PEMBELI DI PASAR INDUK CIKURUBUK TASIKMALAYA DITINJAU DARI PERSPEKTIF PRAGMATIK
}

\author{
Yuni Ertinawati ${ }^{1}$, Ai Siti Nurjamilah ${ }^{2}$ \\ Universitas Siliwangi ${ }^{1,2}$ \\ Surel: yuniertinawati@unsil.ac.id ${ }^{1}$ \\ aisitinurjamilah@unsil.ac.id ${ }^{2}$
}

\begin{abstract}
Abstrak
Penggunaan kata sapaan dalam peristiwa tutur merupakan bagian dari keterampilan berkomunikasi. Penggunaan kata sapaan dalam peristiwa tutur harus memperhatikan aturan-aturan dalam penggunaannya. Berdasarkan penelitian di Pasar Induk Cikurubuk Kota Tasikmalaya yang bervariasi dalam penggunaan kata sapaan, maka penelitian ini bertujuan untuk mengetahui bagaimana penggunaan kata sapaan oleh penjual dan pembeli di Pasar Induk Cikurubuk Kota Tasikmalaya. Bagaimana penggunaan kata sapaan kekerabatan yang digunakan di lingkungan Pasar Induk Cikurubuk Kota Tasikmalaya. Apa saja kata sapaan yang digunakan di dalam tuturan antara penjual dan pembeli di Pasar Induk Cikurubuk Kota Tasikmalaya. Bagaimanakah ragam sapaan yang muncul di dalam respons petutur dan Faktorfaktor apa saja yang melatarbelakangi penggunaan sapaan tersebut di dalam respons. Metode penelitian yang digunakan berjenis kualitatif. Sampel diambil dengan kategori variabel berupa jenis pekerjaan, jenis kelamin, dan usia. Data penelitian diperoleh dengan cara simak dan rekam, yaitu pengamatan serta penyimakan dengan cara menyadap pemakaian bahasa dari informan. Teknik pengumpulan data dilakukan dengan simak bebas libat cakap, observasi, dan dokumentasi. Subjek dalam penelitian ini adalah penjual dan pembeli di sekitar Pasar Induk Cikurubuk Kota Tasikmalaya. Hasil penelitian menunjukkan perbendaharaan yang dimiliki kedua subjek meliputi empat bentuk kata sapaan seperti kata ganti orang kedua, nama diri, dan kata kekerabatan. Data pertama memiliki kata kekerabatan seperti Pak (Bapak) dan Neng (Eneng), data kedua memiliki kata kekerabatan seperti Teh (Teteh), data ketiga terdapat kata kekerabatan sepertinBibi, as data keempat memiliki kata kekerabatan yakni Mbak, kata sapaan yang terdapae pada data kelima yaitu Mang (Mamang), pada data keenam terdapat kata sapaan Aa dan Kang (Akang). Dari daftar kata sapaan yang muncul tersebut, dapat kita beri ciri bahwa kata sapaan yang digunakan seluruhnya adalah kata sapaan dalam bahasa Sunda, kecuali Ibu dan Bapak yang bersifat netral. Hal ini membuktikan bahwa bahasa Sunda di Kota Tasikmalaya khususnya di Pasar Induk Cikurubuk Kota Tasikmalaya masih merupakan bahasa pergaulan yang pertama. Faktor yang paling berperan dalam mengucapkan kata sapaan dalam percakapan adalah tingkat usia penutur, tentunya setelah jenis kelamin.
\end{abstract}

Kata Kunci: Kata Sapaan, penjual dan pembeli, bahasa 


\begin{abstract}
The use of greetings in speech events is part of communication skills. The use of greeting words in speech events must pay attention to the rules in their use. Based on research in the Cikurubuk Main Market of Tasikmalaya City which varies in the use of greeting words, this study aims to find out how to use the greeting words by sellers and buyers in the Cikurubuk Central Market of Tasikmalaya City. How to use the greeting word kinship that is used in the Cikurubuk Mother Market in Tasikmalaya City What are the words sapanan used in speech between sellers and buyers in the Cikurubuk City market in Tasikmalaya. What are the various greetings that appear in the response of the speaker and what factors are behind the use of the greeting in the response. Samples were taken with a variable category in the form of type of work, gender and age. Research data obtained by listening and recording, namely observation and listening by tapping the use of language from the informant. Data collection techniques were carried out with free involvement with proficiency, observation, and documentation. The subjects in this study were sellers and buyers around the Cikurubuk market. The results showed that the treasury of the two subjects included four forms of greetings such as second person pronouns, self names, and kinship words. The first data has kinship words like Pak (Bapak) and Neng (Eneng), the second data has kinship words such as Tea (Teteh), the third data contains kinship words such as Aunt, the fourth data has kinship words namely Ma'am, greeting words contained in the fifth data namely Mang (Mamang), in the sixth data there are greeting words Aa and Kang (Akang). From the list of greetings that appear, we can characterize that the greeting words used are entirely greetings in Sundanese, except for the neutral mother and father. This proves that the Sundanese language in the City of Tasikmalaya especially in the Cikurubuk market is still the first social language. The most important factor in saying greetings in a conversation is the age of the speaker, of course after the sex.
\end{abstract}

Keywords: Greetings, seller and buyer, language

\section{PENDAHULUAN}

Tuhan menciptakan manusia dalam IImsalah seorang partisipan, belum tentu berbagai suku dan bangsa. Setiap sukuidikdapath diterimarosecara nyaman oleh bangsa memiliki ciri dan budaya ${ }^{2}$ partisipan laìn.

masing-masing. Hampir dipastikan budaya dapat mempengaruhi gaya berkomunikasi setiap orang, baik dalam komunikasi verbal dan nonverbal. Perbedaan gaya berkomunikasi ini dapat terjadi dalam percakapan antar penutur dan mitratutur yang berasal dari budaya yang berbeda, bahkan ketika mereka berbicara dalam bahasa yang sama. Fenomena ini seringkali menghasilkan kesalahpahaman antara keduanya,
Masyarakat memerlukan bahasa untuk dapat berkomunikasi satu sama lain. Bahasa ini dapat dijadikan ciri terpenting dari suatu masyarakat, sebab melalui bahasa keanggotaan seseorang di dalam masyarakat dapat diidentifikasi. Bahasa yang digunakan di dalam suatu masyarakat bahasa adalah sama. Suhardi dan Sembiring (Kushartanti dkk, 2007:55) mencontohkan bahwa orang Indonesia dari Sabang sampai 
Merauke, menganggap bahwa kita memakai bahasa yang sama, bahasa Indonesia. Dengan sendirinya, kita membentuk suatu masyarakat bahasa yang sama, masyarakat bahasa Indonesia. Menurut Suhardi dan Sembiring (2007:48), keberagaman bahasa ditentukan oleh berbagai aspek luar bahasa, seperti kelas sosial, jenis kelamin, etnisitas, dan umur. Sebagian besar aspek tersebut merupakan hal-hal yang berkaitan dengan pemakai bahasa itu. Adanya perbedaan dialek dan aksen pada masyarakat merupakan bukti keberagaman itu yang keberadaannya dipengaruhi oleh aspek-aspek sosial.

Penelitian yang penulis lakukan mencermati gejala sosial kebahasaan yang terjadi di daerah Pasar Induk Cikurubuk kota Tasikmalaya. Masyarakat yang beraktivitas di pasar tersebut dominan etnis Sunda. Masyarakat suku Sunda pada umumnya bertutur menggunakan bahasa Sunda dalam pergaulan sehari-hari. Penggunaan bahasa Sunda dipengaruhi oleh faktorfaktor seperti nilai-nilai budaya dan sistem kemasyarakatan yang berlaku. Nilai budaya masyarakat Sunda tampak pada sistem kekerabatan, yang dikenal dengan istilah pancakaki (silsilah keturunan), sedangkan sistem kemasyarakatan mengelompokkan anggota masyarakat ke dalam hirarki-hirarki tertentu, misalnya pengelompokan berdasarkan tempat, keadaan materi, prestise feodalistis, dan profesi mata pencaharian. Faktor nilai budaya dan sistem kemasyarakatan ini lebih jauh berkaitan erat dengan sistem sapaan dalam bahasa Sunda. Sistem sapaan muncul akibat adanya interaksi sosial.

Sumampouw (Purwo, 2000:220) menegaskan bahwa setiap tindak ujaran yang dihasilkan dalam peristiwa ujaran yang tercipta karena adanya interaksi sosial bersemuka dengan ragam apapun, salah satu seginya yang penting adalah sistem penyapaan. Sistem sapaan dalam interaksi sosial memiliki sebutan lain yaitu tutur sapa. Kridalaksana (1982:14) menjelaskan bahwa sistem tutur sapa yakni sistem yang mempertautkan seperangkat kata-kata atau ungkapanungkapan yang dipakai untuk menyebut dan memanggil para pelaku dalam suatu peristiwa bahasa.

Kartomiharjo mengatakan bahwa sapaan merupakan salah satu komponen bahasa yang penting karena dalam sapaan tersebut dapat ditentukan suatu interaksi tertentu akan berlanjut. Walaupun sebagian besar pembicara tidak menyadari betapa pentingnya penggunaan sapaan, tetapi karena secara naluriah setiap pembicara akan berusaha berkomunikasi secara jelas, maka dalam berkomunikasi, dengan bahasa apapun, sapaan hampir selalu digunakan.

Penggunaan sapaan dalam berkomunikasi tidak hanya dilihat dari cara penutur memanggil atau menyapa petuturnya. Hal yang menarik untuk diteliti adalah bagaimana petutur menggunakan sapaan tertentu untuk menjawab sapaan penutur. Dalam hal ini respons petutur juga harus diperhatikan. Bahasa adalah penggunaan kode yang merupakan Sabungan fonem sehingga membentuk kata dengan aturan sintaksis untuk membentuk kalimat yang memiliki arti.

Bahasa memiliki fungsi yaitu untuk berkomunikasi antar anggota masyarakat. Sebagai alat komunikasi antar masyarakat, bahasa merupakan saluran perumusan maksud yang melahirkan perasaan dan memungkinkan adanya kerja sama antar individu. Selain itu, bahasa juga berfungsi sebagai medium 
untuk melakukan tindakan dan cerminan budaya penuturnya. Wardaugh (Oktavianus, 2006:3), menyatakan bahwa bahasa merupakan sistem lambang bunyi yang bersifat arbitrer yang digunakan untuk komunikasi manusia.

Definisi ini mengimplikasikan bahwa bahasa manusia memiliki sistem dan keteraturan-keteratuan yang dapat dikaji secara ilmiah. Bunyi-bunyi yang dihasilkan oleh alat ucap manusia direalisasikan dengan lambang-lambang, sehingga bunyi-bunyi itu dapat diamati. Lambang-lambang tersebut dalam bahasa tulis dapat berupa kata, frasa, klausa, dan kalimat, dan digunakan dalam komunikasi untuk menyampaikan suatu pesan atau maksud.

Kridalaksana (Oktavianus, 2006:4), menambahkan bahwa bahasa merupakan sistem lambang bunyi yang arbitrer yang digunakan oleh para anggota masyarakat untuk bekerjasama, berinteraksi, dan mengidentifikasikan diri. Penggunaan bahasa dengan baik menekankan pada aspek komunikatif bahasa. Hal itu berarti bahwa harus memperhatikan sasaran bahasa yang akan digunakan. Hal yang harus diperhatikan adalah kepada siapa akan menyampaikan bahasa tersebut.

Oleh sebab itu, unsur-unsur. pendidikan, agama, status sosial, dan lingkungan sosial tidak boleh diabaikan. Masyarakat Indonesia pada umumnya sering menggunakan bahasa daerah untuk berkomunikasi dalam kehidupan sehari-hari. Bahasa daerah merupakan bahasa ibu atau bahasa pertama yang diperoleh anak dari lingkungannya. Mempelajari bahasa pertama merupakan salah satu perkembangan menyeluruh anak menjadi anggota penuh suatu masyarakat. Bahasa memudahkan anak mengekspresikan gagasan, kemauannya dengan cara yang benar-benar dapat diterima secara sosial.

Bahasa merupakan media yang dapat digunakan untuk memperoleh nilai-nilai budaya, moral, agama, dan nilai-nilai lain dalam masyarakat. Sedangkan bahasa Indonesai merupakan bahasa kedua yang diperoleh dari lingkungan formal atau jenjang pendidikan dan hanya digunakan ketika situasi resmi atau ketika berbicara dengan orang berlainan daerah. Sebagai bahasa nasional, bahasa Indonesia berfungsi sebagai, lambang-lambang nasional, lambang identitas nasional, alat pemersatu berbagai masyarakat yang berbeda-beda latar belakang sosial budaya dan bahasanya, dan alat perhubungan antar budaya dan daerah.

Bangsa Indonesia memiliki khazanah budaya yang beragam. Dari suku, adat istiadat, bahasa, nyanyian, tarian, serta panggilan atau kata sapaan untuk seseorang. Kata sapaan yang memiliki ciri khas tersendiri. Kata sapaan merupakan kata yang dipakai untuk menegur, menyapa, mengajak bercakapcakap, dan sebagainya. Kata sapaan berguna sebagai ajakan bercakap, teguran, ucapan kata atau frasa untuk saling merujuk dalam pembicaraan dan yang berbeda menurut sifat hubungan di antâra pembicara itu, seperti: Anda, Ibu, Saudara dan sebagainya.

\section{METODE}

Penelitian yang dilakukan berjenis kualitatif yang memusatkan analisis pada kualitas data. Analisis data yang dilakukan merupakan analisis penelitian lapangan. Bodgan (1982:27-29) mengemukakan karakteristik penelitian kualitatif, yaitu: (1) menggunakan lingkungan alamiah sebagai sumber data 
langsung; (2) sifatnya deskriptif analitik; (3) tekanan penelitian ada pada proses bukan pada hasil; (4) sifatnya induktif; dan (5) mengutamakan makna.

Penelitian tentang bentuk kata sapaan antara penjual dan pembeli di Pasar Induk Cikurubuk Kota Tasikmalaya ini menggunakan pendekatan deskriptif. Pendekatan deskriptif adalah pendekatan yang dilakukan semata-mata hanya berdasarkan pada fakta yang ada atau fenomena yang memang secara empiris hidup pada penutur-penuturnya, sehingga yang dihasilkan atau dicatat berupa wujud bahasa seperti apa adanya.

Perolehan data dalam penelitian ini adalah metode simak yakni penjaringan data yang dilakukan dengan menyimak penggunaan bahasa (Kesuma, 2007:43). Dalam pelaksanaan penjaringan data, metode simak diwujudkan lewat teknik dasar dan teknik lanjutan.

Populasi penelitian ini adalah pertuturan masyarakat Kota Tasikmalaya khususnya pertuturan seputar kegiatan perdagangan yang terjadi di pasar Cikurubuk. Sampel diambil dengan kategori variabel berupa jenis pekerjaan, jenis kelamin dan usia. Metode penyediaan data yang digunakan dalam penelitian ini adalah metode simak, yaitu pengamatan serta penyimakan dengan cara menyadap pemakaian bahasa dari informan. Pend

Teknik pengumpulan data dilakukan dengan simak bebas percakapan objek penelitian. Mahsun (2005:219) menjelaskan bahwa teknik ini dimaksudkan peneliti menyadap perilaku berbahasa di dalam suatu peristiwa tutur dengan tanpa keterlibatannya dalam peristiwa tutur tersebut. Jadi, peneliti hanya sebagai pengamat. Teknik ini digunakan dengan dasar pemikiran bahwa perilaku berbahasa hanya dapat benar-benar dipahami jika peristiwa berbahasa itu berlangsung dalam situasi yang sebenarnya yang berada dalam konteks yang lengkap.

\section{HASIL DAN PEMBAHASAN}

Data dalam penelitian ini berupa percakapan masyarakat yang berlangsung di lingkungan Pasar Induk Cikurubuk. Korpus data diambil melalui observasi partisipan dengan teknik simak-rekam-catat. Korpus dalam penelitian ini yaitu berupa tuturan. Tuturan yang dimaksud adalah tuturan yang mengandung kata sapaan yakni kata yang digunakan seorang pembicara untuk menyapa lawan bicaranya. Dalam penggunaannya, kata sapaan dipengaruhi oleh beberapa faktor, seperti usia, jenis kelamin, status sosial lawan bicara, dan sebagainya. Bertolak dari uraian tersebut, kata sapaan dalam dunia perdagangan di Pasar Induk Cikurubuk Kota Tasikmalaya akan dipaparkan ke dalam beberapa kategori. Kata sapaan tersebut selanjutnya akan dibahas berdasarkan faktor-faktor yang mempengaruhinya.

Beberapa data percakapan dikelompokkan ke dalam 4 klasifikasi utama, berdasarkan status penutur-petutur, jenis kelamin dan faktor usia. Klasifikasi tersebut adalah: (1) penutur laki-laki kepadacpetutur perempuan; (2) penutur perempuan kepada petutur laki-laki; (3) penutur perempuan kepada petutur perempuan; dan (4) penutur laki-laki kepada petutur laki-laki.

Penganalisisan data dilakukan dua tahap, pertama yaitu penganalisisan wujud sapaan yang digunakan oleh penutur-petutur, kedua yaitu penganalisisan sapaan dalam respons petutur dengan memperhatikan faktor-faktor yang melatar belakanginya. Istilah 
penutur diterapkan pada orang yang pertama kali mengajak berbicara pada rekaman percakapan, sedangkan petutur adalah orang yang diajak bicara oleh penutur.

\section{Penutur Laki-laki kepada Petutur Perempuan}

Di dalam klasifikasi ini peneliti menemukan 9 data dengan rincian 9 percakapan antara Pedagang dan pembeli. Peneliti akan membahas kesembilan percakapan tersebut.

\section{Data 1}

\section{Konteks:}

Percakapan antara Pak Dodi dengan Ibu Ita, ketika peneliti berkunjung ke sebuah kios milik Ibu Ita pada tanggal 13 Juli 2019 sekitar pukul 09.30 WIB. Percakapan menggunakan bahasa lisan. Bentuk penyampaianya menggunakan bahasa Sunda yang digunakan seharihari. Tuturan yang dilakukan dalam berinteraksi dilakukan sangat singkat yaitu menanyakan harga dagangan yang dijual pedagang.

\section{Lokasi:}

Di sebuah kios buah-buahan, Pasar Cikurubuk-Tasikmalaya.

\section{Penutur:}

Seorang ibu (penjual buah-buahan).

Petutur:

Bapak Dodi (pembeli).

Situasi tutur:

Seorang Bapak yang hendak membeli buah-buahan.

Pembeli

: Bu, sabaraha pangaos jeruk?

(Bu, berapa harga jeruk?)

Pedagang : Sapuluh rebu, Pak? (Sepuluh ribu, Pak).

Pembeli : Gening mahal pisan? Dalapan rebu tiasa teu?

(Kok, mahal amat sih?

Delapan ribu bisa tidak?)

Pedagang : Henteu.

(Tidak).

Pembeli : Meser $1 \mathrm{~kg}$, cekap.

(Beli $1 \mathrm{~kg}$, cukup).

Pedagang : Muhun.

(Iya).

Pembeli : Pami ieu alpuket

sabaraha?

(Kalau ini Alpukat berapa?)

Pedagang : Lima belas rebu.

(Lima belas ribu).

Pembeli : Meser $2 \mathrm{~kg}$, pami ieu naon?

(Beli, 2 kg, kalau ini apa?)

Pedagang : Muhun. Cincau. (Iya, cincau).

Pembeli : Sabaraha pangaosna?

(Berapa harganya?)

Pedagang : Dua rebu lima ratus.

(Dua ribu lima ratus).

Pembeli : Beli satu saja.

Data 1, kata sapaan yang digunakan adalah jenis kata sapaan dengan istilah nonkekerabatan, yaitu Pak (Bapak) dan panggilan untuk perempuan yang dianggap masih muda dalam bahasa Sundaha Neng.st:Pemilihan penggunaan sapaan Pak oleh penutur bukan berarti bahwa penutur dan petutur berkerabat. Hal ini memperlihatkan bahwa penutur sebagai pedagang menghormati penutur yakni pembeli, sebagai orang yang dituakan.

Kata sapaan Pak berasal dari kata bapak digunakan oleh para pembeli maupun pedagang di Pasar Cikurubuk Kota Tasikmalaya untuk menyapa lakilaki yang lebih tua tetapi usia belum 
begitu lanjut (belum pantas disapa kakek), walaupun tidak ada hubungan kekerabatan atau bahkan yang tidak saling mengenal, tetapi yang digunakan dalam kata sapaan ini selalu tidak penuh.

Dalam konteks percakapan di atas, Pak Dodi membeli buah di kios milik Ibu Ita. Kata sapaan Pak semakin banyak dipakai dalam menyapa laki-laki yang usianya lebih tua dari penyapa dan sudah memiliki anak.

Salah satu faktor semakin seringnya kata sapaan ini digunakan adalah berubahnya kondisi sosial ekonomi, kesan-kesan tradisional dalam komunikasi semakin bergeser. Jadi, kata sapaan Pak dalam hubungan nonkekerabatan juga bisa dikatakan menggambarkan kondisi-kondisi kekinian dalam penggunaan bahasa khususnya kata sapaan. Sedangkan pemilihan sapaan Neng oleh petutur menunjukkan bahwa pembeli dirasa masih muda meskipun ia adalah seorang ibu.

Sapaan Neng ini merupakan nomina. Kata sapaan Neng dalam konteks percakapan di atas berasal dari kata Neneng yang digunakan oleh seseorang kepada perempuan (biasanya masih muda). Kata sapaan Neng merupakan kata sapaan tidak penuh dari Neneng.Untuk menganalisis sapaan dalam respons petutur, dalam haleinici pedagang, diperlukan latar belakang pengetahuan yang umum. Pedagang menggunakan sapaan Neng dengan pandangan bahwa pembeli berusia lebih muda darinya.

Penggunaan istilah ini berulangulang di dalam respons pedagang. Hal ini menunjukkan bahwa respons tersebut ditujukan secara khusus kepada pembeli, karena kemungkinan kios sedang dalam keadaan ramai dan banyak pengunjung. Jadi, kata Neneng/Neng artinya sebutan kepada seorang perempuan. Kata sapaan ini lumrah atau umum digunakan dalam lingkungan perdagangan dan lain-lain.

\section{Data 2}

\section{Konteks:}

Percakapan antara Dadang (A) yang berusia 45 tahun dengan Dita (B) berusia 33 tahun ketika Dadang hendak menawarkan becak pada tanggal 13 Juli 2019 sekitar pukul 11.00 WIB. Percakapan menggunakan bahasa lisan. Bentuk penyampaianya menggunakan bahasa Sunda yang digunakan seharihari. Peristiwa ini terjadi di pinggir jalan di Pasar Cikurubuk Tasikmalaya.

Berikut ini dialog antara Dadang dan Dita:

A: Neng, bade becana?

(Neng, mau naik becak?)

B: Moal Kang, punteun.

(Tidak Kang, maaf).

Kata sapaan Kang adalah kata sapaan tidak penuh yang berasal dari kata Kakang. Kata sapaan Kakang dalam konteks ini digunakan untuk menyapa seorang laki-laki yang lebih tua meskipun tidak ada hubungan kekerabatan. Dalam konteks pembicaraan di atas seorang yang bernama Dita lebih muda ditawari becak oleh Dadang. Kata sapaahaini Sdigunakan oleh kalangan warga masyarakat sekitar Pasar Cikurubuk Kota Tasikmalaya dan umumnya digunakan untuk menyapa orang-orang dari kalangan nonpriyayi. Meski demikian, penyapa dapat saja dari kalangan keluarga priyayi.

\section{Penutur Perempuan kepada Petutur Perempuan}

\section{Data 3}




\section{Lokasi:}

Di sebuah toko pakaian.

\section{Penutur:}

Wanita muda, suku Sunda, berusia 28 tahun.

\section{Petutur:}

Pegawai toko, suku Sunda, berusia sekitar 22 tahun.

\section{Situasi Tutur:}

Pembeli bertanya kepada pelayan yang berjaga toko.

$\begin{array}{ll}\text { Pembeli } & \text { : Teh, pangaos acuk ieu } \\ & \text { sabaraha? } \\ & \text { (Teh, harga baju ini } \\ & \text { berapa?) } \\ \text { Penjaga toko } & \text { : Tilu puluh lima rebu. } \\ & \text { (Tiga puluh lima ribu). } \\ \text { Pembeli } & \text { : Wah, sadayana ieu tilu } \\ & \text { Puluh lima rebu? } \\ & \text { (Wah, semuanya ini } \\ & \text { tiga puluh lima ribu?) } \\ \text { Penjaga toko } & \text { : Muhun, tilu puluh } \\ & \text { lima rebu. } \\ & \text { (Iya tiga puluh ribu). }\end{array}$

Data 3 menunjukkan variasi sapaan yang berbeda dari data sebelumnya. Penutur, dalam hal ini pembeli, memanggil penjaga toko dengan sapaan Teh (Teteh). Teteh adalah kata sapaan yang diambil dari bahasa daerah yakni bahasa Sunda yang memiliki arti sebagai kakak perempuan yang dituakan. Kedua bahwa pembeli menganggap penjaga toko seperti kakak perempuannya sehingga disapa Teh (Teteh). Dengan demikian, peneliti dapat menggolongkan sapaan tersebut ke dalam poin petutur menyapa penutur dengan sapaan Teh (Teteh).

Sapaan ini pun termasuk ke dalam istilah kekerabatan dalam bahasa Sunda. Sapaan Teteh digunakan untuk memanggil kakak perempuan. Teteh dalam masyarakat Sunda mengalami perluasan makna sehingga kini digunakan bukan hanya untuk menyapa kakak perempuan, tetapi juga untuk menyapa perempuan pada umumnya yang berusia dewasa.

Respons pedagang sebagai petutur dalam percakapan di atas menyapa penutur dengan sapaan Teteh mungkin disebabkan penampilan penutur sebagai pembeli tampak seperti perempuan dewasa, dalam hal ini tidak tampak seperti ibu-ibu pada umumnya. Faktor usia berperan di sini. Oleh sebab itu petutur tidak menyebut dengan sapaan Ibu ataupun Neng.

\section{Data 4}

\section{Lokasi:}

Di sebuah kios buah-buahan, tetapi pembeli dan pedagang berbeda dengan data 1.

\section{Penutur:}

Pembeli.

\section{Petutur:}

Pedagang buah.

\section{Situasi tutur:}

Seorang perempuan membeli mentimun.

Pembeli

: Bibi ieu bonteng suri?

(Bibi ini Timun Suri?)

Pedagang

: Muhun. (Iya).

: Bibi, hoyong meser

Pembel

ssatengah kilo.

(Bibi, mau beli setengah kilo).

Pedagang : Muhun.

(Iya).

Pembeli

: Nuhun Bi.

(Terima kasih, Bi).

Data 4, penutur (pembeli) memanggil petutur dengan sapaan $\mathrm{Bi}$ (dari kata sapaan Bibi). Kata sapaan Bi pada konteks percakapan di atas merupakan kata sapaan tidak penuh 
yang berasal dari kata Bibi, yang digunakan oleh seorang anak untuk menyebut adik perempuan dari orang tuanya, baik adik dari ayahnya maupun ibunya. Tetapi, terkadang juga digunakan untuk memanggil orang yang lebih tua (bagi yang tidak saling mengenal sebelumnya). Namun, sapaan ini juga seringkali digunakan oleh masyarakat Sunda untuk memanggil para pedagang barang maupun jasa. Pada percakapan ini, penutur menyebut Bi (Bibi) dengan maksud memanggil pedagang buah sebagaimana biasa pedagang lainnya disapa oleh masyarakat Sunda.

\section{Data 5}

\section{Lokasi:}

Di sebuah toko sepatu dan sandal.

\section{Penutur:}

Pembeli.

\section{Petutur:}

Pedagang sepatu dan sandal.

\section{Situasi tutur:}

Seorang perempuan hendak membeli sandal.

$\begin{array}{ll}\text { Pembeli } & \text { : Mbak, ieu pangaosna } \\ & \text { sabaraha? } \\ & \text { (Mbak ini harganya } \\ & \text { berapa?) } \\ \text { Pedagang } & \text { : Dalapan lima, Neng,al } \\ & \text { (delapan lima, Neng)! } \\ \text { Pembeli } & \text { : Teu tiasa kirang ? } \\ & \text { (Tidak bisa kurang?) } \\ \text { Pedagang } & : \text { Henteu Neng atos pas. } \\ & \text { (Tidak, Neng sudah } \\ & \text { pas). } \\ \text { Pembeli } & : \text { Kirangan atuh saalit } \\ & \text { mah. } \\ & \text { (Kurangi saja sedikit). } \\ \text { Pedagang } & : \text { Ih, Teteh mah. } \\ & \text { (Ih, Teteh). }\end{array}$

Percakapan di atas, penutur (pembeli) menyebut pedagang dengan kata sapaan Mbak. Kata sapaan Mbak merupakan kata sapaan terhadap wanita yang lebih tua dari daerah Jawa digunakan untuk menyapa orang perempuan yang lebih tua tetapi usia tidak terpaut jauh dan tidak ada hubungan kekerabatan. Kata sapaan ini memiliki karakteristik yang sama dengan kata sapaan Kakang. Keduanya hanya dibedakan pada peruntukan karena perbedaan jenis kelamin. Petutur, yaitu pedagang buah, menggunakan sapaan Neng untuk memanggil pembelinya. Seperti telah dijelaskan pada analisis data 1, sapaan Neng digunakan untuk memanggil perempuan yang relatif masih muda, di batas usia remaja.

Respons petutur dengan memanggil penutur dengan sapaan Neng memperlihatkan bahwa faktor usia pembeli yang berperan dalam peristiwa tutur ini. Petutur menganggap penutur lebih muda darinya dari segi usia dan penampilan. Dikarenakan di daerah Tasikmalaya banyak imigran dari Jawa sehingga membuat kata sapaan ini menjadi salah satu jenis kata sapaan yang juga diakui keberadaannya di tengah masyarakat Sunda.

\section{Penutur Laki-laki kepada Petutur} Perempuan.

Peneliti menemukan 3 data percakapan yang relevan dengan klasifikasi ini.

\section{Data 6 \\ Lokasi:}

Di depan pasar.

Penutur:

Pedagang jam tangan kaki lima.

\section{Petutur:}


Pembeli.

Situasi tutur:

Di depan pasar Cikurubuk terdapat banyak pedagang kaki lima, terutama pedagang jam tangan.

$\begin{array}{ll}\text { Pembeli } & \text { Mang jam tangan } \\ \text { sabarahaan? }\end{array}$

(Mang jam tangannya berapa?)

Pedagang : Rupi-rupi, anu 30 aya bade anu 35 aya.

(Macam-macam, yang Rp30.000,00 ada yang Rp35.000,00 ada).

Pembeli : Mana Mang?

(Yang mana Mang ?)

Pedagang : Ieu.

(Ini)

Pembeli : Ari nu alit ieu sabaraha?

(Kalau yang kecil ini berapa?)

Pedagang : : Rupi-rupi Neng, aya anu tiga puluh ribuan oge.

(Macam-macam

Neng, ada yang Rp30.000,00 juga).

Percakapan di atas, penutur (pembeli) menyebut pedagang dengan kata sapaan Mang (Mamang). Kata sapaan Mang (Mamang) merupakan kata sapaan terhadap laki-laki yanglebih tua dari daerah Sunda, Jawa Barat, apabila dalam bahasa Indonesia Mamang itu sama dengan Paman. Sedangkan pedagang jam tangan, menggunakan sapaan Neng untuk memanggil pembelinya. Seperti telah dijelaskan pada analisis data sebelumnya, kata sapaan Neng digunakan untuk memanggil perempuan yang relatif masih muda.
Respons petutur dengan memanggil penutur dengan sapaan Neng memperlihatkan bahwa faktor usia si pembeli yang berperan dalam peristiwa tutur ini. Petutur menganggap penutur lebih muda darinya dari segi usia dan penampilan. sebenarnya lazim digunakan di daerah Jawa Barat yang mayoritas orang Sunda.

\section{Data 7 \\ Konteks:}

Percakapan antar Nining (A) Ibu muda berusia 33 tahun dengan Anggi (B) seorang pedagang sayuran yang kirakira berusia 28 tahunan ketika Nining akan membeli sayuran pada tanggal 3 Agustus 2019 sekitar pukul 13.00 WIB. Percakapan menggunakan bahasa lisan. Bentuk penyampaianya menggunakan bahasa Sunda yang digunakan seharihari. Tempat kejadian dalam pembahasaan jenis kata sapaan ini sama dengan kata sapaan Mamang pada kategori jenis kata sapaan nonkekerabatan, yaitu di sekitar pintu masuk Pasar Cikurubuk Kota Tasikmalaya. Penggunaan sapaan dilihat dari bentuk sapaan kepada yang lebih muda dari penyapa.

Berikut ini dialognya.

A: Jang, aya seureuh teu?

(Jang, ada daun sirih tidak?)

B: Kosong Bu nuju seusah.

(Kosong Bu lagi susah).

Kata sapaan Jang merupakan kata sapaan tidak penuh yang berasal dari kata Ujang, kata sapaan Ujang dipakai untuk menyapa orang laki-laki yang biasanya masih muda asalnya dari Jawa Barat atau orang Sunda. Sedangkan Kata sapaan Bu merupakan kata sapaan tidak penuh dari ibu dipakai seorang anak untuk memanggil orang tua perempuan. 
Kata Sapaan Ibu sebagaimana bapak biasanya dipakai oleh kalangan keluarga guru, pegawai negeri sipil dan keluarga yang secara capaian ekonomi termasuk golongan menengah atau priyayi bagi masyarakat kata sapaan Bu berasal dari kata Ibu, namun kata sapaan ini selalu dipakai tidak penuh.

Kata sapaan $\mathrm{Bu}$ biasanya dipakai untuk menyapa orang perempuan yang usianya kira-kira sebaya dengan Ibu si penutur atau penyapa walaupun tidak ada hubungan kekerabatan atau bahkan tidak saling mengenal sekalipun. Penggunaan kata sapaan Bu, sebagaimana kata sapaan pak juga memiliki karakteristik yang sama. Jenis kata sapaan ini semakin banyak digunakan di kalangan masyarakat.

\section{Penutur Laki-laki kepada Petutur Laki-laki}

Peneliti menemukan data percakapan yang termasuk ke dalam klasifikasi ini.

\section{Data 8}

Lokasi:

Di sebuah kios HP (konter)

\section{Penutur:}

Pembeli, anak muda

Petutur:

Pedagang

Situasi tutur:

Seorang calon pembeli membeli pulsadidik

Pembeli : A, meser pulsa anu sapuluh rebu.

(A, beli pulsa yang sepuluh ribu).

Penjual : Mangga, kartu naon, Kang? (Silahkan, kartunya apa, Kang?)

Pembeli : Kartu m3, A. (Kartu m3, A).
Penjual

: Oh, muhun atuh, sok tulis nomerna.

(Oh, iya, silakan tulis nomornya).

Pembeli

: Atos, $\mathbf{A}$.

(Sudah, A).

Penjual

: Atos masuk acan

Kang?

(Sudah masuk atau

belum

Kang?)

Pembeli

: Atos Kang, janteun sabaraha?

(Sudah Kang, jadi berapa?)

Penjual

: Dua belas rebu, Kang.

(Dua belas ribu, Kang).

Pembeli

: Oh muhun ieu. Nuhun,

A.

(Oh iya ini, terima kasih, A).

Akang adalah sapaan setara dengan Aa yang dalam bahasa Sunda berarti kakak laki-laki. Kini sapaan ini juga digunakan untuk memanggil laki-laki yang lebih tua meskipun tidak berkerabat. Selain itu, pada percakapan ini penutur menggunakan istilah kekerabatan Aa untuk menyapa petuturnya.

${ }_{h}$ Hal ini dilatarbelakangi oleh pengetahuanaspenutur bahwa petutur berusia lébih tua darinya. Sebenarnya, sapaan Aa adalah sapaan yang digunakan ketika hendak memanggil kakak laki-laki. Namun, seperti halnya beberapa sapaan lain dalam bahasa Sunda, sapaan Aa pun mengalami perluasan sehingga digunakan untuk memanggil laki-laki yang lebih tua secara umum. 


\section{Data 9}

\section{Konteks:}

Percakapan antara Dani (A) seorang pembeli kelontongan yang hendak membeli di kios Mas Yadi (B) pada tanggal 13 Juli 2019 pukul 14.00 WIB. Percakapan menggunakan bahasa lisan. Bentuk penyampaianya menggunakan bahasa Sunda yang digunakan seharihari. Kios Rima berada di jajaran kioskios lainnya di Pasar Cikurubuk Tasikmalaya. Di sela-sela obrolan, ketika pemilik kios melayani pembeli, peneliti mengamati interaksi yang terjadi antara penjual (bu Rima) dengan salah satu pembeli (Siti). Peneliti mengetahui nama pembeli dari bu Rima disalinan nota pembelian buku.

Berikut percakapan yang peneliti simak:

A

B

: Mas, aya kispray?

(Mas, ada kispray?)

: Aya

(Ada)

Kata sapaan Mas digunakan untuk menyapa orang laki-laki yang lebih tua untuk kalangan terpelajar atau pegawai (priyayi). Kata sapaan Mas di sini sama sekali tidak mewakili hubungan kekerabatan, namun hanyalah sebagai sapaan untuk sebuah bentuk penghargaan atau penghormatan kepada yang lebih tua meski dari segi usia tidak terpaut terlalu jauh.

lurnat lir

Kata sapaan adalah kata yang muncul dalam pertuturan untuk memanggil orang yang diajak bicara. Di dalam tutur sapa, biasanya kata sapaan memiliki peranan yang penting, terutama agar tuturan yang ingin disampaikan tepat diterima oleh orang yang diajak bicara.

Setelah menganalisis percakapan yang terwakili oleh 9 data, peneliti mendapati bahwa kata sapaan yang digunakan dalam tuturan seputar kegiatan perdagangan di Pasar Induk
Cikurubuk Kota Tasikmalaya didominasi oleh istilah kekerabatan, seperti Ibu, Teteh, Emang, Akang, dan Aa. Selain itu adapula kata sapaan yang tergolong nominal, seperti Neng.

Berdasarkan daftar kata sapaan yang muncul tersebut, dapat kita beri ciri bahwa kata sapaan yang digunakan seluruhnya adalah kata sapaan dalam bahasa Sunda, kecuali Ibu dan Bapak yang bersifat netral. Hal ini membuktikan bahwa bahasa Sunda di Kota Tasikmalaya khususnya di Pasar Induk Cikurubuk masih merupakan bahasa pergaulan yang pertama.

Kata-kata sapaan tersebut merupakan bukti yang menunjang teori Kridalaksana mengenai jenis kata sapaan dalam bahasa Indonesia (dalam hal ini disesuaikan dengan bahasa Sunda). Respons petutur terhadap tuturan penutur dari segi sapaan tidak sepenuhnya dapat diketahui. Namun, dapat diambil garis besarnya bahwa sapaan yang digunakan petutur tidak selalu bersifat simetris, misalnya IbuAnak, Kakak-Adik, dan lain-lain. Faktor yang paling berperan dalam respons petutur adalah tingkat usia penutur, tentunya setelah jenis kelamin.

\section{PENUTUP}

Simpulan

kan Penelitian ${ }^{\prime}$ mengenai kata sapaan dalam tuturan yang dilakukan antara penjual dan pembeli dalam kegiatan perdagangan yang dilakukan di Pasar Induk Cikurubuk, Kota Tasikmalaya menghasilkan beberapa ciri penting yang dapat disimpulkan sebagai berikut.

a. Kata sapaan yang digunakan sebagian besar merupakan istilah kekerabatan dalam masyarakat Sunda, misalnya Ibu, Teteh, Emang, Akang, dan Aa. Ada juga dalam 
beberapa tuturan muncul kata sapaan seperti Neng. Kata sapaan tersebut masuk pada kategori pronomina.

b. Ragam sapaan yang muncul di dalam respons petutur kebanyakan bersifat asimetris, meskipun antara penuturpetutur sama-sama menggunakan isitilah kekerabatan. Contohnya penggunaan sapaan Ibu-Neng, Teteh- Emang,

c. Faktor-faktor yang melatarbelakangi penggunaan sapaan tersebut di dalam respons terutama adalah faktor jenis kelamin dan usia. Petutur merespons tuturan dan sapaan penutur tidak berdasarkan sapaan yang digunakan penutur untuk memanggil petutur, melainkan melihat pada jenis kelamin penutur dan perkiraan usianya. Oleh sebab itu banyak sapaan asimetris yang digunakan di dalam respons.

\section{Saran}

Berdasarkan temuan-temuan dalam penelitian, dengan ini peneliti memaparkan beberapa rekomendasi yang dianggap relevan.

a. Bagi Mahasiswa

Penelitian ini diharapkan mampu menginspirasi mahasiswa untuk lebih menggali lagi wawasan keilmuan linguistik dan pragmatik, khususnya dalam bidang keterampilan berbicara Mahasiswa yang kompeten dalam berbicara terutama dalam kemampuan bertindak tutur maka akan mudah menjalani kehidupan sosial yang dihadapinya.

\section{b. Bagi Masyarakat}

Penelitian ini diharapkan menjadi tolok ukur kemampuan berkomunikasi masyarakat dimanapun berada khususnya di Tasikamalaya. Selain itu, penulis berharap masyarakat memperbaiki kekurangan-kekurangan pada saat berkomunikasi dengan orang lain sehingga terjalin rasa saling menghargai terutama dalam bidang keterampilan berbicara dalam konteks jual beli antara pedagang dan pembeli.

c. Bagi Calon peneliti

Calon peneliti dapat mengembangkan penelitian ini karena penelitian ini perlu dilakukan penelitian lanjutan. Pada penelitian mendatang perlu ditarik data yang lebih luas, tidak hanya terpaku pada tuturan masyarakat di daerah sunda saja namun dapat dilakukan pada masyarakat di daerah lainnya. Ini dimaksudkan agar kesimpulan yang dihasilkan dari penelitian tersebut nantinya dapat memiliki cakupan yang lebih luas dan tidak hanya berkisar pada masyarakat sunda saja.

\section{DAFTAR PUSTAKA}

Djajasudarma, F. 2006. Metode Linguistik. Bandung: PT. Refika Aditama.

Kridalaksana, H. 1982. Fungsi Bahasa dan Sikap Bahasa. Jakarta: Penerbit Nusa Indah.

Mahsun, M.S. 2005. Metode Penelitian Bahasa. Jakarta: PT Rajagrafindo Persada.

Subiyatningsih. 2008. Kaidah Sapaan Bahasa SMadura dalam Identitas Madura dalam Bahasa dan Sastra. Sidoarjo: Balai Bahasa Surabaya.

Suhardi, B. dan Sembiring, B.C. 2007. Aspek Sosial Bahasa dalam Pesona Bahasa. Jakarta: PT. Gramedia Pustaka Utama.

Sumampouw, E. 2000. Pola Penyapaan Bahasa Indonesia dalam Interaksi Verbal dengan Latar Multilingual dalam Kajian Serba Linguistik untuk 
Anton Moeliono. Jakarta: Pereksa Wardhaugh, R. 2006. An Introduction to Bahasa. Sociolinguistics. Edisi kelima. Oxford: Blackwell Publishing.

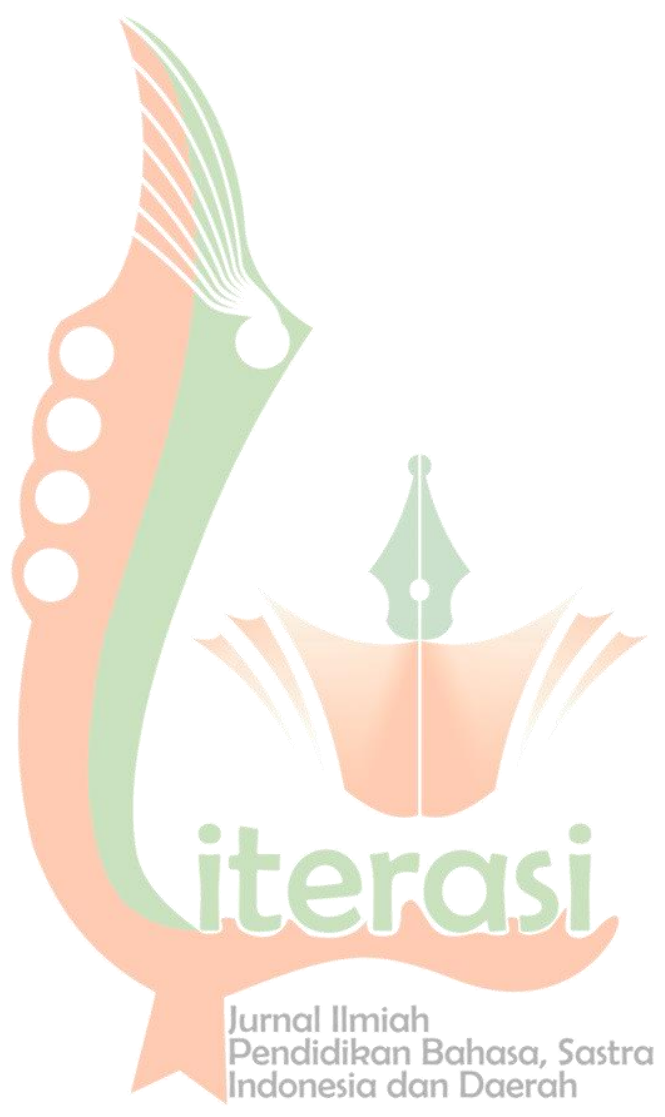

